Catarina Vizetto-Duarte, Luísa Custódio, Luísa Barreira, Manuela Moreira da Silva, Amélia P. Rauter, Fernando Albericio and João Varela*

\title{
Proximate biochemical composition and mineral content of edible species from the genus Cystoseira in Portugal
}

DOI 10.1515/bot-2016-0014

Received 16 February, 2016; accepted 28 June, 2016; online first 22 July, 2016

\begin{abstract}
Macroalgae are valuable resources for human consumption in many countries. This work reports for the first time a comparative evaluation of the nutritional properties of five edible macroalgae from the genus Cystoseira, namely $C$. humilis, $C$. tamariscifolia, $C$. nodicaulis, C. compressa and C. baccata. For this purpose, their proximate composition was determined in terms of moisture, ash, and total contents of protein, lipids, carbohydrates and mineral profile. Cystoseira tamariscifolia and C. baccata were the species that in general had the higher ash, protein and lipid contents, while the highest levels of moisture and total carbohydrates were detected in $C$. nodicaulis and $C$. compressa. Cystoseira species had also high amounts of minerals, especially of potassium, calcium and iron, and a favorable $\mathrm{Na} / \mathrm{K}$ ratio. The present study shows that Cystoseira has a balanced nutritional composition, suitable for human consumption, and that its intake can contribute to a healthy and well-balanced diet.
\end{abstract}

\footnotetext{
*Corresponding author: João Varela, Centre of Marine Sciences, University of Algarve, Faculty of Sciences and Technology, Ed. 7, Campus of Gambelas, Faro, Portugal, e-mail: jvarela@ualg.pt Catarina Vizetto-Duarte, Luísa Custódio and Luísa Barreira: Centre of Marine Sciences, University of Algarve, Faculty of Sciences and Technology, Ed. 7, Campus of Gambelas, Faro, Portugal Manuela Moreira da Silva: Center of Marine and Environmental Research (CIMA), University of Algarve, Campus de Gambelas, Faro, Portugal
}

Amélia P. Rauter: Center of Chemistry and Biochemistry, Department of Chemistry and Biochemistry, Faculty of Sciences University of Lisbon, Campo Grande, Ed. C8, Piso 5, 1749-016 Lisbon, Portugal Fernando Albericio: Institute for Research in Biomedicine, Barcelona Science Park, Baldiri Reixac 10, 08028 Barcelona, Spain; CIBERBBN, Networking Centre on Bioengineering, Biomaterials and Nanomedicine, Barcelona Science Park, Baldiri Reixac 10, 08028 Barcelona, Spain; Department of Organic Chemistry, University of Barcelona, Martí i Franqués 1-11, 08028 Barcelona, Spain; and School of Chemistry, University of KwaZulu-Natal, 4001 Durban, South Africa
Keywords: brown algae; Cystoseira; minerals; nutritional profile; proximate composition.

\section{Introduction}

It is estimated that the world's population will grow to nine billion by mid-century, putting substantial demands on the planet's food supply. Macroalgae (also known as "seaweeds") are major coastal resources that are valuable for human consumption in many countries. Edible macroalgae are widely consumed in Asia, but the demand has grown worldwide, especially in the USA and Europe. Seaweeds are a highly nutritive food that additionally can be eaten in raw salads, soups, cookies, meals, and condiments (Aguilera-Morales et al. 2005). The nutritional value ascribed to macroalgae along with their non-animal nature makes them particularly appropriate for use in the food and additive industries (Lordan et al. 2011). However, compared to land plants, the chemical composition of macroalgae has been poorly investigated and most of the available information refers to species traditionally consumed in Japanese cuisine. There has also been a growing interest in the mineral content of macroalgae, which is higher than that of many terrestrial plants (Tabarsa et al. 2012). Cystoseira (C. Agardh) is one of the most widely distributed genera of the class Phaeophyceae and is abundant not only on European coasts, but also in the Pacific and Indian Oceans (Valls and Piovetti 1995). Several species belonging to the Phaeophyceae, such as Laminaria japonica (Areschoug) and Sargassum naozhouense (C.K. Tseng and Lu Baoren) (Peng et al. 2013, Patra et al. 2015), among many others, are traditionally used as food. Although Cystoseira species are not commonly used as food, they are defined as edible and are potential candidates for food products, nutraceutical and pharmaceutical preparations (Andrade et al. 2013) and thus could be considered as alternative sources of nutritional elements. Therefore, the focus of the present study was to evaluate the proximate composition and mineral content of five species of brown 
macroalgae belonging to the genus, namely Cystoseira humilis Schousboe ex Kützing, C. tamariscifolia (Hudson) Papenfuss, C. nodicaulis (Withering) M. Roberts, C. compressa (Esper) Gerloff and Nizamuddin and C. baccata (S.G. Gmelin) P.C. Silva, as well as to consider and discuss the use of these macroalgae as food and/or incorporated in supplements. To the best of the authors' knowledge this is the first report on the proximate composition and mineral contents of these Cystoseira species.

\section{Materials and methods}

\section{Algal biomass sampling and preparation}

Cystoseira humilis, C. compressa, C. tamariscifolia, C.nodicaulis and $C$. baccata were collected in the middle/lower intertidal areas of the Algarve (Albufeira and Odeceixe, Portugal) coast, in May 2010, during low tide (Table 1). Specimens were identified by Dr. Aschwin Engelen (Centre of Marine Sciences, University of Algarve, Portugal) and Dr. Javier Cremades Ugarte (Faculty of Sciences, University of A Coruña). Voucher specimens of $C$. compressa (code number MB004), $C$. humilis (code number MB007), C. tamariscifolia (code number MB016), C. nodicaulis (code number MB014-2), and C. baccata (code number MB001) are deposited at the Centre of Marine Sciences, University of Algarve. Individual thalli were washed thoroughly with freshwater upon arrival in the laboratory to remove epiphytes and washed again with distilled water. In order to have enough biomass for the determination of the proximate composition and minerals, six replicates were prepared by combining two to three individual thalli of a given species. Each replicate sample was assessed for moisture content while fresh and was then oven-dried, ground into a fine powder and stored in tightly closed plastic bags containing silica gel until analysis.

\section{Proximate biochemical analysis}

For the determination of the proximate composition, six replicates were prepared as described in the previous section. Moisture was determined by drying the replicates at $95^{\circ} \mathrm{C}$ until constant weight as described by the AOAC method (AOAC 1995). Ash content was measured by weight difference before and after $5 \mathrm{~h}$ of incineration in a muffle furnace at $525^{\circ} \mathrm{C}$. Total nitrogen content of dried samples was determined using a Vario EL III elemental analyzer (Elementar, Hanau, Germany), and the protein content was estimated by multiplying the total nitrogen content by a nitrogen conversion factor of 6.25 (Lourenço et al. 2002). Total lipid content was determined by a modified method of Bligh and Dyer (Pereira et al. 2013). Carbohydrate content was assumed to be the remaining biomass and was calculated from the difference between $100 \%$ and the summed contents of ash, protein and lipids (MarinhoSoriano et al. 2006).

\section{Mineral content}

Mineral elements were analyzed by atomic absorption spectrometry (AAS). Approximately $300 \mathrm{mg}$ of the dried powder from three of the replicate samples for each species were digested by microwave (Milestone Ethos Touch, Sorisole, Italy) in high-pressure Teflon vessels. The digestion was made using $6 \mathrm{ml}$ of Fluka supra-pure $\mathrm{HNO}_{3}$ (65\%), $1 \mathrm{ml}$ of Riedel-Dehaen p.a. $\mathrm{HClO}_{4}(70 \%)$ and $1 \mathrm{ml}$ of Merck supra-pure $\mathrm{H}_{2} \mathrm{O}_{2}$ (30\%) (ETHOS PLUS, 2001). A procedural blank was prepared and included in each digestion batch of 10 samples. Calcium, magnesium, sodium, potassium, iron, manganese and zinc were analyzed by flame AAS with an air-acetylene flame in an atomic absorption spectrometer (GBC Avanta Sigma, Victoria, Australia). The accuracy of the analytical procedure was assessed by the analysis of certified reference material (BCR-60 - aquatic plant Lagarosiphon major, from the Institute for Reference

Table 1: Date and location of sample collection of different Cystoseira species from Portugal.

\begin{tabular}{lllll}
\hline & Date & GPS coordinates & Location (beach, county) & $\begin{array}{l}\text { Voucher specimen } \\
\text { code number }\end{array}$ \\
\hline C. humilis & $07-05-2010$ & $37^{\circ} 4^{\prime} 36.19^{\prime \prime} \mathrm{N} 8^{\circ} 18^{\prime} 36.49^{\prime \prime} \mathrm{W}$ & Manuel Lourenço, Albufeira & MB007 \\
C. compressa & $08-05-2010$ & $37^{\circ} 4^{\prime} 35.83^{\prime \prime} \mathrm{N} 8^{\circ} 16^{\prime} 33.74^{\prime \prime} \mathrm{W}$ & Arrifes, Albufeira & $\mathrm{MB} 004$ \\
C. tamariscifolia & $07-05-2010$ & $37^{\circ} 5^{\prime} 24.31^{\prime \prime} \mathrm{N} 8^{\circ} 11^{\prime} 9.72^{\prime \prime} \mathrm{W}$ & Olhos de Água, Albufeira & $\mathrm{MB} 016$ \\
C. nodicaulis & $07-05-2010$ & $37^{\circ} 4^{\prime} 36.19^{\prime \prime} \mathrm{N} 8^{\circ} 18^{\prime} 36.49^{\prime \prime} \mathrm{W}$ & Manuel Lourenço, Albufeira & $\mathrm{MB} 014-2$ \\
C. baccata & $11-05-2010$ & $37^{\circ} 26^{\prime} 41.48^{\prime \prime} \mathrm{N} 8^{\circ} 48^{\prime} 3.90^{\prime \prime} \mathrm{W}$ & Odeceixe, Aljezur & MB001 \\
\hline
\end{tabular}


Materials and Measurements, JRC-IRMM, Belgium). Procedural blanks always accounted for $<1 \%$ of the metal concentrations in samples. Values were expressed as $\mathrm{g} \mathrm{kg}^{-1}$ dry weight (DW) for Ca, $\mathrm{Mg}$, $\mathrm{Na}$ and $\mathrm{K}_{\text {or }} \mathrm{mg} \mathrm{kg}^{-1} \mathrm{DW}$ for Fe, $\mathrm{Mn}$ and $\mathrm{Zn}$.

\section{Statistical analysis}

Biological replicates were collected on a given date and location (Table 1) and were used for the determination of the proximate $(n=6)$ and mineral composition $(n=3)$. Significant differences were assessed by analysis of variance (ANOVA) and significance between means was analyzed by the Tukey HSD test $(\mathrm{p}<0.05)$. SPSS statistical package for Windows (release 15.0, SPSS Inc.) was used.

\section{Results}

The present study aimed to evaluate the proximate composition of different Cystoseira species (namely C. humilis, C. compressa, C. tamariscifolia, $C$. nodicaulis and $C$. baccata) collected on the Algarve coast, Portugal. Results are summarized in Table 2. The moisture content ranged from $49 \%$ of wet weight (WW) in C. tamariscifolia to $63 \%$ in C. compressa, while the ash levels varied from $7 \%$ in C. compressa to $24 \%$ in C. tamariscifolia. Cystoseira tamariscifolia also presented the lowest total carbohydrate (54\%) and the highest protein (13\%) contents. Conversely, $C$. nodicaulis, along with $C$. compressa, had the highest total carbohydrate levels (73\%) and low protein contents (9-10\%). The highest concentration of total lipids was $11 \%$ in C. baccata, followed by C. tamariscifolia (10\%) and the lowest value was observed in $C$. nodicaulis (4\%, Table 2 ).

The mineral content of the samples was also evaluated and results are given in Table 3. The total of all macrominerals, expressed as the sum of $\mathrm{K}, \mathrm{Na}, \mathrm{Ca}$ and $\mathrm{Mg}$, ranged from $40 \mathrm{~g} \mathrm{~kg}^{-1}$ in $C$. baccata to $101 \mathrm{~g} \mathrm{~kg}^{-1}$ in $C$. compressa.
However, in terms of microminerals, C. tamariscifolia had the highest (1013 $\mathrm{mg} \mathrm{kg}^{-1}$ ) and C. compressa the lowest (173 mg kg $\mathrm{k}^{-1}$ ) content. Potassium was the most abundant macromineral in $C$. compress $a, C$. humilis and $C$. baccata (60, 30 and $22 \mathrm{~g} \mathrm{~kg}^{-1}$, respectively). Sodium content ranged from $8 \mathrm{~g} \mathrm{~kg}^{-1}$ in C. humilis to $16 \mathrm{~g} \mathrm{~kg}^{-1}$ in $C$. tamariscifolia. The $\mathrm{Na} / \mathrm{K}$ ratios varied from 0.15 in $C$. compressa and 0.97 in $C$. tamariscifolia (Table 3). In C. tamariscifolia and C. nodicaulis, calcium was the most abundant macromineral (around $26 \mathrm{~g} \mathrm{~kg}^{-1}$ in both species). Magnesium concentration varied from $5.7 \mathrm{~g} \mathrm{~kg}^{-1}$ in $C$. nodicaulis to $19 \mathrm{~g} \mathrm{~kg}^{-1}$ in $C$. compressa.

Among the microminerals detected, iron was the most abundant ranging from $110 \mathrm{mg} \mathrm{kg}^{-1}$ in C. baccata to $508 \mathrm{mg} \mathrm{kg}^{-1}$ in C. tamariscifolia. Cystoseira tamariscifolia also had the highest content of manganese (398 $\mathrm{mg} \mathrm{kg}^{-1}$ ), while the lowest manganese content was observed in C. compress $a$ (14 $\mathrm{mg} \mathrm{kg}^{-1}$ ), which also contained the lowest amount of zinc $\left(9.4 \mathrm{mg} \mathrm{kg}^{-1}\right)$. The highest content of zinc was found in $C$. nodicaulis (114 $\mathrm{mg} \mathrm{kg}^{-1}$ ), although $C$. tamariscifolia and C. baccata also had values above $100 \mathrm{mg} \mathrm{kg}^{-1}$ (Table 3).

\section{Discussion}

This study reports for the first time the proximate composition and mineral profiles of five species of Cystoseira found on the coast of Algarve (Portugal), namely C. humilis, C. tamariscifolia, C. nodicaulis, C. compressa and $C$. baccata. The first parameter assessed was the moisture content of fresh specimens. As found in most brown macroalgae, the moisture values for fresh specimens were high. For example, the moisture determined for $C$. compressa was $63 \%$, which is similar to the value reported for Sargassum (C. Agardh) (Holdt and Kraan 2011).

Most ash contents obtained for Cystoseira are in agreement with published values for other Phaeophyceae, such as those of Ascophyllum (Stackhouse) (18-27\%), Fucus (Linnaeus) (19-30\%) and Sargassum (14-44\%). The only

Table 2: Proximate composition of different Cystoseira species from Portugal, including moisture (\% of wet weight), ash, total protein, total lipids, carbohydrates (\% of dry weight).

\begin{tabular}{lrrrrr}
\hline & C. humilis & C. compressa & C. tamariscifolia & C. nodicaulis & C. baccata \\
\hline Moisture & $57.06^{\mathrm{b}}$ & $63.05^{\mathrm{a}}$ & $48.99^{\mathrm{d}}$ & $58.95^{\mathrm{b}}$ & $51.43^{\mathrm{c}}$ \\
Ash & $20.35^{\mathrm{a}} \mathrm{b}$ & $7.30^{\mathrm{d}}$ & $23.85^{\mathrm{a}}$ & $13.45^{\mathrm{c}}$ & $19.10^{\mathrm{b}}$ \\
Protein & $10.34^{\mathrm{b}}$ & $10.16^{\mathrm{b}}$ & $12.52^{\mathrm{a}}$ & $9.20^{\mathrm{c}}$ & $12.46^{\mathrm{a}}$ \\
Lipids & $5.22^{\mathrm{c}}$ & $9.45^{\mathrm{b}}$ & $9.57^{\mathrm{b}}$ & $4.31^{\mathrm{d}}$ & $10.92^{\mathrm{a}}$ \\
Carbohydrates & 64.09 & 73.09 & 54.06 & 73.04 & 57.52 \\
\hline
\end{tabular}

Values are mean $(n=6)$. Different superscript letters indicate that, for each variable, differences between species are significant at $p=0.05$. 
Table 3: Mineral content of different Cystoseira species from Portugal.

\begin{tabular}{|c|c|c|c|c|c|c|}
\hline Mineral & Symbol & C. humilis & C. compressa & C. tamariscifolia & C. nodicaulis & C. baccata \\
\hline \multicolumn{7}{|c|}{ Expressed as $\mathrm{g} \mathrm{kg}^{-1}$ dry biomass } \\
\hline Calcium & $\mathrm{Ca}$ & $23.70^{\mathrm{b}}$ & $13.08^{c}$ & $25.82^{\mathrm{a}}$ & $26.50^{\mathrm{a}}$ & $9.43^{d}$ \\
\hline Magnesium & $\mathrm{Mg}$ & $12.90^{\mathrm{b}}$ & $18.53^{\mathrm{a}}$ & $6.56^{c}$ & $5.69^{d}$ & $6.78^{c}$ \\
\hline Sodium & $\mathrm{Na}$ & $7.56^{\mathrm{e}}$ & $8.94^{\mathrm{d}}$ & $16.36^{\mathrm{a}}$ & $11.61^{\mathrm{b}}$ & $10.81^{c}$ \\
\hline Potassium & $\mathrm{K}$ & $29.78^{b}$ & $60.02^{\mathrm{a}}$ & $16.87^{d}$ & $15.98^{\mathrm{e}}$ & $22.10^{c}$ \\
\hline $\mathrm{Na} / \mathrm{K}$ ratio & & 0.25 & 0.15 & 0.97 & 0.73 & 0.49 \\
\hline Total & & 73.94 & 100.57 & 65.61 & 59.78 & 39.69 \\
\hline \multicolumn{7}{|c|}{ Expressed as $\mathrm{mg} \mathrm{kg}^{-1}$ dry biomass } \\
\hline Iron & $\mathrm{Fe}$ & $171.88^{c}$ & $149.74^{\mathrm{d}}$ & $508.06^{a}$ & $413.14^{b}$ & $109.59^{\mathrm{e}}$ \\
\hline Manganese & $\mathrm{Mn}$ & $152.18^{c}$ & $14.27^{\mathrm{e}}$ & $398.46^{\mathrm{a}}$ & $193.54^{b}$ & $108.35^{d}$ \\
\hline Zinc & $\mathrm{Zn}$ & $41.16^{c}$ & $9.43^{d}$ & $105.99^{b}$ & $113.82^{\mathrm{a}}$ & $106.73^{b}$ \\
\hline Total & & 365.22 & 173.44 & 1012.51 & 720.50 & 324.67 \\
\hline
\end{tabular}

Values are means $(n=3)$. Different superscript letters indicate that, for each variable, differences between species are significant at $p=0.05$.

exception was the ash content for $C$. compressa (7\%), which is lower than the usual range (Holdt and Kraan 2011).

The protein values obtained in this study (9-13\% DW) are of the same order as those reported in previous studies of brown algae. According to the review by Holdt and Kraan (2011), the protein content of Ascophyllum can range from 1.2 to $12 \%$, and that of Sargassum from 9 to $20 \%$. The protein content is often lower in brown macroalgae than in green and red macroalgae (Holdt and Kraan 2011).

In general, macroalgae have low lipid contents, usually below $5 \%$ of dry matter (Burtin 2003). However, C. compressa, C. tamariscifolia and C. baccata had total lipid contents higher than 9.4\%. Gosch et al. (2012) showed that brown macroalgae typically have the highest content of total lipids amongst seaweeds. Some species have values of total lipids higher than $15 \%$. This is particularly true in members of the order Dictyotales, which consistently display total lipid contents between 11 and 20\% DW (McDermid and Stuercke 2003). Our results are in accordance with these data, showing that the closely related Cystoseira (Fucales) algae also contain relatively high lipid contents. The fatty acid profiles of these five species of Cystoseira have been reported previously (Vizetto-Duarte et al. 2015) and showed that their polyunsaturated fatty acids (PUFA) corresponded to $29-46 \%$ of the total fatty acids detected. In addition, Cystoseira species have a high nutritional value due to their high PUFA vs. saturated fatty acids (SFA) ratios and low n-6 PUFA/n-3 PUFA ratios (Vizetto-Duarte et al. 2015).

In this study, the carbohydrate content varied from 42 to 73\% DW in Cystoseira species. Hadj Ammar et al. (2015) showed lower total carbohydrate contents (13-45\% DW) for $C$. compress $a, C$. sedoides and $C$. crinita collected in June in Tunisia. However, other brown algae collected throughout the year, such as Sargassum vulgare, have previously been reported with a carbohydrate content of $68 \%$ DW (Marinho-Soriano et al. 2006). Variation in temperature, salinity and solar radiation among the sites of collection might explain the aforementioned differences, as all of these environmental factors seem to have a significant correlation with carbohydrate content (Marinho-Soriano et al. 2006). Moreover, carbohydrate content might also vary with the physiological state (e.g. developmental stage; Holdt and Kraan 2011) of the alga. Previous studies have suggested an inverse relationship between carbohydrates and proteins in macroalgae (Mouradi-Givernaud et al. 1993, Marinho-Soriano et al. 2006, Kumar et al. 2015), which is also observed in our samples.

Macroalgae are known to have a high mineral content, usually higher than that of most terrestrial plants (OrtegaCalvo et al. 1993). In fact, edible seaweeds are considered to be valuable nutritional resources due to their high content of several essential minerals (Bocanegra et al. 2009). Potassium and sodium values of the macroalgae studied here were higher than those reported for land vegetables, such as lettuce and spinach (USDA 2015). Nevertheless, the $\mathrm{Na} / \mathrm{K}$ ratios were below 1.0 in all the species of Cystoseira studied (0.15-0.97, Table 3), which is interesting from a nutritional point of view, as diets with a high $\mathrm{Na} / \mathrm{K}$ ratio have been associated with the incidence of hypertension (Taboada et al. 2010). For instance, $\mathrm{Na} / \mathrm{K}$ ratio in sausages is 4.89 (Ortega-Calvo et al. 1993). High values of calcium and magnesium were also observed, as compared with those of land vegetables (USDA 2015). Regarding microminerals, C. tamariscifolia and C. nodicaulis displayed remarkably high iron contents $\left(>400 \mathrm{mg} \mathrm{kg}^{-1}\right)$ compared with those of other Cystoseira species (Table 3) and of commercial seaweeds such as Fucus, Laminaria, Undaria, Chondrus and Porphyra (33-103 mg kg-1 ; Rupérez 
2002). The same conclusion can be drawn with respect to the iron concentrations usually found in terrestrial vegetables (35-233 mg kg-1; USDA 2015). In a study by Rupérez (2002), Fucus vesiculosus contained $55 \mathrm{mg} \mathrm{kg}^{-1}$ of Mn and $71 \mathrm{mg} \mathrm{kg}^{-1}$ of $\mathrm{Zn}$. The concentrations of these trace elements detected by us (Table 3) also fall within the ranges observed in previous reports on macroalgae, except for C. compress $a$ that exhibited lower values. Mineral composition is also known to vary according to seasonal, environmental, geographical and physiological factors (Mabeau and Fleurence 1993).

Taken together, our results indicate that Cystoseira has a balanced nutritional composition suitable for human consumption, and that its intake could contribute to a healthy and well-balanced diet. This study showed that species of Cystoseira have high ash and carbohydrate contents, and relatively high total lipids compared to other macroalgae. Mineral analysis also showed that these species contain useful amounts of macrominerals and trace elements. Among the nutritional profiles described here for the first time, $C$. tamariscifolia stands out for its high content of ash (and therefore, minerals) and total protein, its high lipid content, and relatively low carbohydrate content. Cystoseira tamariscifolia also contains high $\mathrm{Ca}$ and was the species with highest micromineral concentrations, especially $\mathrm{Fe}$ and $\mathrm{Mn}$. The $\mathrm{Na} / \mathrm{K}$ ratio of all species was suitable for human diet. Together with recent studies on the edibility of Cystoseira and the need for alternative sources of non-animal food, our results show that these species could be used as alternative sources of valuable food products.

Acknowledgments: Financial support for this work was provided by the SEABIOMED (PTDC/MAR/103957/2008) and XTREMEBIO (PTDC/MAR-EST/4346/2012) projects and CCMAR/Multi/04326/2013 funded by the Foundation for Science and Technology (FCT) and the Portuguese National Budget. C. Vizetto-Duarte acknowledges an FCT doctoral research grant (SFRH/BD/81425/2011). L. Custódio is supported by FCT Investigator Programme (IF/00049/2012).

\section{References}

Aguilera-Morales, M., M. Casas-Valdez, S. Carrillo-Domìnguez, B. González-Acosta and F. Perez-Gil. 2005. Chemical composition and microbiological assays of marine algae Enteromorpha spp. as a potential food source. J. Food Compos. Anal. 18: 79-88.

Andrade, P.B., M. Barbosa, R.P. Matos, G. Lopes, J. Vinholes, T. Mouga and P. Valentão. 2013. Valuable compounds in macroalgae extracts. Food Chem. 138: 1819-1828.
AOAC. 1995. Official methods of analysis. Association of Official Analytical Chemists, Arlington, VA.

Bocanegra, A., S. Bastida, J. Benedí, S. Ródenas and F.J. SánchezMuniz. 2009. Characteristics and nutritional and cardiovascular-health properties of seaweeds. J. Med. Food 12: 236-258.

Burtin, P. 2003. Nutritional value of seaweeds. Electron. J. Environ. Agric. Food Chem. 2: 498-503.

Gosch, B.J., M. Magnusson, N.A. Paul and R. de Nys. 2012. Total lipid and fatty acid composition of seaweeds for the selection of species for oil-based biofuel and bioproducts. GCB Bioenergy 4: 919-930.

Hadj Ammar, H., S. Lajili, R. Ben Said, D. Le Cerf, A. Bouraoui and H. Majdoub. 2015. Physico-chemical characterization and pharmacological evaluation of sulfated polysaccharides from three species of Mediterranean brown algae of the genus Cystoseira. Daru. 23: 1.

Holdt, S.L. and S. Kraan. 2011. Bioactive compounds in seaweed: functional food applications and legislation. J. Appl. Phycol. 23: 543-597.

Kumar, K.S., K. Ganesan and P.V. Subba Rao. 2015. Seasonal variation in nutritional composition of Kappaphycus alvarezii (Doty) Doty - an edible seaweed. J. Food Sci. Technol. 52: 2751-2760.

Lordan, S., R.P. Ross and C. Stanton. 2011. Marine bioactives as functional food ingredients: potential to reduce the incidence of chronic diseases. Mar. Drugs 9: 1056-1100.

Lourenço, S.O., E. Barbarino, J.C. De-Paula, L.O.S. Pereira and U.M.L. Marquez. 2002. Amino acid composition, protein content and calculation of nitrogen-to-protein conversion factors for 19 tropical seaweeds. Phycol. Res. 50: 233-241.

Mabeau, S. and J. Fleurence. 1993. Seaweed in food products: biochemical and nutritional aspects. Trends Food Sci. Tech. 4: 103-107.

Marinho-Soriano, E., P.C. Fonseca, M.A. Carneiro and W.S. Moreira. 2006. Seasonal variation in the chemical composition of two tropical seaweeds. Bioresour. Technol. 97: 2402-2406.

McDermid, K.J. and B. Stuercke. 2003. Nutritional composition of edible Hawaiian seaweeds. J. Appl. Phycol. 15: 513-524.

Mouradi-Givernaud, A., T. Givernaud, H. Morvan and J. Cosson. 1993. Annual variations of the biochemical composition of Gelidium latifolium (greville) Thuret et Bornet. Hydrobiologia. 260/261: 607-612.

Ortega-Calvo, J.J., C. Mazuelos, B. Hermosin and C. Saiz-Jimenez. 1993. Chemical composition of Spirulina and eukaryotic algae food products marketed in Spain. J. Appl. Phycol. 5: 425-435.

Patra, J.K., G. Das and K.-H. Baek. 2015. Chemical composition and antioxidant and antibacterial activities of an essential oil extracted from an edible seaweed, Laminaria Japonica L. Molecules 20: 12093-12113.

Peng, Y., E. Xie, K. Zheng, M. Fredimoses, X. Yang, X. Zhou, Y. Wang, B. Yang, X. Lin, J. Liu and Y. Liu. 2013. Nutritional and chemical composition and antiviral activity of cultivated seaweed Sargassum naozhouense Tseng et Lu. Mar. Drugs 11: 20-32.

Pereira, H., L. Barreira, L. Custódio, S. Alrokayan, F. Mouffouk, J. Varela, K.M. Abu-Salah and R. Ben-Hamadou. 2013. Isolation and fatty acid profile of selected microalgae strains from the Red Sea for biofuel production. Energies 6: 2773-2783.

Rupérez, P. 2002. Mineral content of edible marine seaweeds. Food Chem. 79: 23-26.

Tabarsa, M., M. Rezaei, Z. Ramezanpour, J.R. Waaland and R. Rabiei. 2012. Fatty acids, amino acids, mineral contentes and 
proximate composition of some brown seaweeds. J. Phycol. 48: 285-292.

Taboada, C., R. Millán and I. Míguez. 2010. Composition, nutritional aspects and effect on serum parameters of marine algae Ulva rigida. J. Sci. Food Agric. 90: 445-449.

US Department of Agriculture, Agricultural research service. USDA National Database for Standard Reference, Release 28 (2015). Available at: http://ndb.nal.usda.gov/ndb/foods. Accessed on 3 February 2016.

Valls, R. and L. Piovetti. 1995. The chemistry of the cystoseiraceae (Fucales: Pheophyceae): chemotaxonomic relationships. Biochem. Syst. Ecol. 23: 723-745.

Vizetto-Duarte, C., H. Pereira, C. Bruno de Sousa, A.P. Rauter, F. Albericio, L. Custódio, L. Barreira and J. Varela. 2015. Fatty acid profile of different species of algae of the Cystoseira genus: a nutraceutical perspective. Nat. Prod. Res. 29: $1264-1270$

\section{Bionotes}

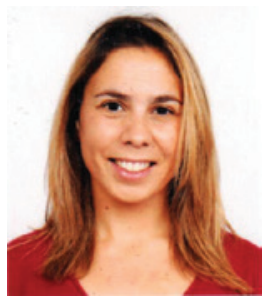

\section{Catarina Vizetto-Duarte}

Centre of Marine Sciences, University of Algarve, Faculty of Sciences and Technology, Ed. 7, Campus of Gambelas, Faro, Portugal

Catarina Vizetto-Duarte is a PhD student at the Centre of Marine Sciences (CCMAR), University of Algarve. She has an MSc in Molecular Genetics and Biomedicine from the University of Lisbon (2009). As a PhD student she is evaluating the nutritional and biomedical applications (especially antioxidant and antitumoral properties) of brown algae, focusing on finding novel bioactive molecules and studying the molecular mechanisms responsible for the said activities in terms of cellular responses to drug exposure, inflammation, cell death (apoptosis/necrosis) versus cell survival.

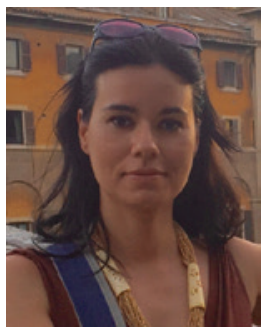

Luísa Custódio

Centre of Marine Sciences, University of Algarve, Faculty of Sciences and Technology, Ed. 7, Campus of Gambelas, Faro, Portugal

Luísa Custódio has a PhD in Biotechnological Sciences and carried out her post-doctoral research at the University of Algarve and CCMAR. Presently she is a research assistant hired by CCMAR under the framework of the FCT investigator program and her research has focused on the search for bioactive compounds in marine organisms and halophyte species, and the evaluation of the nutritional profile of edible organisms (e.g. algae, halophytes and sea cucumbers).

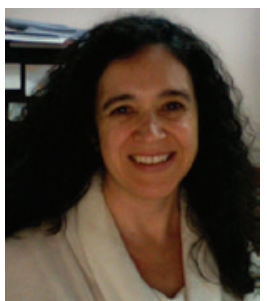

\section{Luísa Barreira}

Centre of Marine Sciences, University of Algarve, Faculty of Sciences and Technology, Ed. 7, Campus of Gambelas, Faro, Portugal

Luísa Barreira has been an Assistant Professor in the Chemistry and Pharmacy Department of the Faculty of Sciences and Technology of the University of Algarve since 2007. She has a PhD in Environmental Sciences and Technologies and is currently a senior researcher in MarBiotech for $\mathrm{I}+\mathrm{D}+\mathrm{I}$ of biotechnological applications of marine organisms, from the production of biodiesel and other bioproducts (e.g. phospholipids) from microalgae to the search of natural products with biological activities in marine organisms.

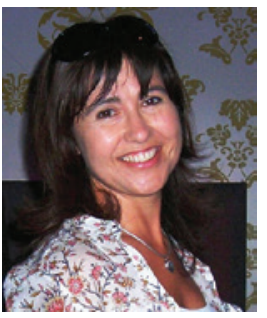

Manuela Moreira da Silva

Center of Marine and Environmental Research (CIMA), University of Algarve, Campus de Gambelas, Faro, Portugal

Manuela Moreira da Silva is an Adjunct Professor at the Institute of Engineering of University of Algarve, PhD in Environmental Sciences and Technology, and a senior researcher of Centre for Marine and Environmental Research (CIMA). Presently, Manuela is the head of the Sanitary Engineering Laboratory at the University of Algarve. Her research interests comprise ecohydrology, phytoremediation of heavy metals, sustainable water management, urban water cycle, water and society and water quality and human health.

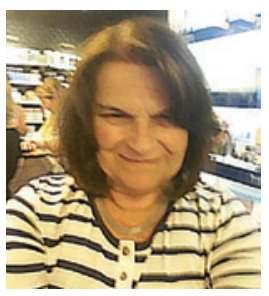

\section{Amélia P. Rauter}

Center of Chemistry and Biochemistry, Department of Chemistry and Biochemistry, Faculty of Sciences University of Lisbon, Campo Grande, Ed. C8, Piso 5, 1749-016 Lisbon, Portugal

Amélia P. Rauter has Tenure at the Faculty of Sciences, University of Lisbon since 2002 and completed her PhD at the Technische Universitaet Graz, Austria, 1982); her research focuses on the discovery of active principles from natural resources and on the molecular design and synthetic organic chemistry. She is the Head of the Carbohydrate Chemistry Group - Centre of Chemistry and Biochemistry (FCUL), and has been serving as an Editor of the RSC Carbohydrate Chemistry book series, an Associated Editor of Mediterranean Journal of Chemistry, and is a member of the European Journal of Organic Chemistry advisory board, and is on the advisory/editorial boards of other natural product/carbohydrate chemistry journals. She is the Secretary of the European Carbohydrate Organization and the Secretary of the IUPAC Division on Organic and Biomolecular Chemistry, she has supervised $19 \mathrm{PhD}$ theses and currently has six additional PhD students; she has published more than 130 papers and book chapters, and authored seven granted patents. 


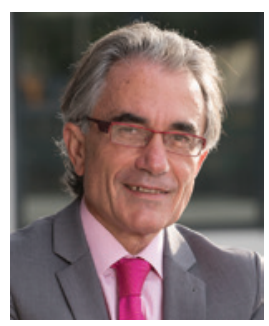

Fernando Albericio

Institute for Research in Biomedicine, Barcelona Science Park, Baldiri Reixac 10, 08028 Barcelona, Spain; CIBER-BBN, Networking Centre on Bioengineering, Biomaterials and Nanomedicine, Barcelona Science Park, Baldiri Reixac 10, 08028 Barcelona, Spain; Department of Organic Chemistry, University of Barcelona, Martí i Franqués 1-11, 08028 Barcelona, Spain; and School of Chemistry, University of KwaZuluNatal, 4001 Durban, South Africa

Fernando Albericio is a Research Professor at the University of KwaZulu-Natal in Durban, South Africa and at the University of Barcelona. He holds a PhD in Chemistry from the University of Barcelona (1980). Following his postdoctoral work (1981-1984) at Tufts University, the Université d'Aix-Marseille, and the University of Minnesota, he was appointed Associate Professor at the University of Barcelona. After a few years, he took up the position of Director of Peptide Research at Milligen-Biosearch, Boston, USA (1992-1994), and then re-joined the University of Barcelona in 1995, when he was promoted to Full Professor. He also served as Executive Director of the Barcelona Science Park (2005-2011). He is currently Editor of the International Journal of Peptide Research and Therapeutics and a Councilor of the American Peptide Society. Recently, he has been honored with a doctorate honoris causa by the Universidad de Buenos Aires (Argentina) and the Vincent du Vigneaud award by the American Peptide Society.

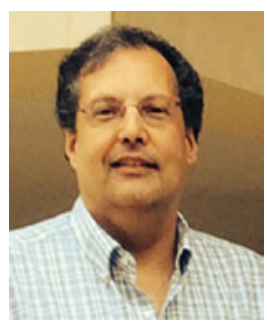

João Varela

Centre of Marine Sciences, University of Algarve, Faculty of Sciences and Technology, Ed. 7, Campus of Gambelas, Faro, Portugal, jvarela@ualg.pt

João Varela is an Assistant Professor at the University of Algarve and Group Leader of the MarBiotech (Marine Biotechnology) research group at the Centre of Marine Sciences (CCMAR). MarBiotech, which has the following research lines (i) searching for novel bioactive compounds in marine organisms, with particular emphasis on microalgae, macroalgae and halophytes; (ii) designing and implementation of biorefineries for the upgrade of algal biomass for biofuel, food and feed production; and (iii) marine organisms (e.g. sea cucumbers and halophytes) as innovative gourmet food. 